\title{
The Social Organization of Merchants' Activities. An Interactionist Study of Urban Marketplaces
}

\author{
Lukasz Marciniak \\ University of Lodz, Poland
}

DOI: http://dx.doi.org/10.18778/1733-8077.16.4.07

\section{Keywords:}

Symbolic

Interactionism;

Bazaar; Street

Vendors; Grounded

Theory; Qualitative

Economic Sociology

\begin{abstract}
The article briefly presents the empirical results of a large research project focused on Polish urban marketplaces, commonly known as bazaars, and their interactional order. Due to the spatial separation and legal regulations concerning bazaar trade, a relatively constant community of market vendors is created in the area of the particular marketplace. The primary activity of each merchant is to offer and sell goods; however, the specificity of marketplace trade results in the necessity to maintain relationships with other vendors to keep this primary activity going. Thus, the activities of merchants are carried out in the same direction for both economic results and performance (sales and profit) and social action, that is, building and managing relations with vendors operating in the same marketplace. A wide range of activities and interaction strategies is developed that create an order of interactions between vendors, both in terms of perceiving and assigning meanings, interpreting, and taking actions. The consequences of such an interactional foundation affect the economic layer of the market, embedding, on the one hand, economic phenomena in social phenomena, and, on the other hand, generating paradoxes of prices and competition-the two economic concepts that cannot be analyzed without their social contexts.
\end{abstract}

Lukasz Marciniak ( $\mathrm{PhD}$ in Sociology) is an Assistant Professor at the University of Lodz, Department of Sociology of Organization and Management. The former Chair and Vice-Chair of the Qualitative Methods Research Network within the European Sociological Association (ESA), co-founder of the Transdisciplinary Qualitative Research Symposium. He was a member of the Advisory Board of the SAGE Handbook of Grounded Theory (ed. Kathy Charmaz and Antony Bryant), editor of the translation of the Polish edition of the Handbook of the Qualitative Research (ed. Norman
Denzin and Yvonne Lincoln). His current academic interests include research on altered states of consciousness, identity transformations, coaching praxis, economic processes embedded in the social, qualitative social research, grounded theory methodology, social pragmatist inquiry, and systemic research. He is also a certified coach and therapist experienced in a transformational systemic approach, organizational consultant for business development.

email address: lukasz.marciniak@uni.lodz.pl 
treet vending is a world-renowned phenomenon that takes many different forms and types. In Poland, street vending is legally organized and localized, and large clusters of various vendors (merchants in Polish legal terminology) create the phenomenon of an urban bazaar-a place where cultures, values, symbols, and meanings intertwine; a place where dozens of interactions, interpretations, and activities occur at any moment. Each of the dimensions of the marketplace, from its spatial organization to economic aspects such as competition or price formation, is an interactional construct whose symbolism and meaning play a key role.

The primary action taken by each merchant is to sell the goods they offer, but the specificity of a bazaar trade means that this primary action cannot be carried out without maintaining relationships with other bazaar vendors. Thus, the activities of merchants are as much focused on the economic result and performance (sales and profit) as on social action, that is, building and managing relations with other merchants in the same marketplace.

The aim of the research on which this article is based was to reconstruct and describe the processes shaping the relations between buyers at marketplaces and the contextual conditions in which they take place. Further, such reconstruction and explanation were to enable understanding of the complexity of the social organization of merchant activity and the importance that this organization may have for economic aspects of the functioning of the marketplace.

\section{Theoretical Background}

The issue of interactions between marketplace vendors has not been widely explored in sociological studies, neither in the cultural dimension of this phenomenon nor in its model approach, as an interactional representation of economic relations at the macro-level. The research conducted so far in the field of marketplaces, both Polish (Misztal 1971; Kurczewski 2010) and international (Geertz 1978; Chiu 2013; Rosales 2013; Papadantonakis 2020), has primarily an anthropological profile, focusing on the local "folklore" of the street vending.

The issues focused on the social context of economic phenomena locate the work at hand among the achievements of economic sociology and market sociology, especially the approach known as the New Economic Sociology (Granovetter 1974; Wasserman and Faust 1994; Carruthers and Babb 2000), which aims to go beyond the model of the economic equilibrium, showing the dynamics, complexity, and multidimensionality of all activities, processes, and economic phenomena that are socially embedded (Granovetter 1985; 1992; DiMaggio 1990). In this dimension, however, it is not about applying or collating economic and social theory as in the case of economic sociology, but it is rather about developing sociology of economic action (Konecki 2007; 2008), the analysis of interactions, building relationships, distancing, and cooperating towards goals of an economic nature (trading goods and generating a profit), and in an economically defined context of the market.

The interest in interactions, interpretations, and actions that construct the order of economic phenomena (from general issues like the market itself to the concept of prices, from the construction of the demand to the origins of economic crisis) is not new in sociological research. From such a paradigmatic perspective, there are classic studies on closing fairs and, more broadly, creating marketing (Prus 1989a; 
1989b; Moeran 2006), the social construction of the value of works of art and wines (Velthuis 2003; Chiffoleau and Laporte 2006), the advertising market (Moeran 2006), the social order of auctions and the way the value on the market is socially constructed (Smith 1990), constructing the financial market (Ho 2009), or economic crimes (Baker and Faulkner 2004). The premises of symbolic interactionism were successfully used in relation to the socio-economic phenomena by Herbert Blumer (1990) himself, taking up the issue of industrialization as a social process and the resulting social changes. On the other hand, studies on work, labor, and market, especially in the urban contexts, have a long tradition in the interactionist legacy, and those classic symbolic interactionist works of Robert Park and Ernest Burgess (1925), Roderick McKenzie (1921), or Everett Hughes (1958) are also a point of reference for this study. The article, and, most of all, the research on which it is based, is a continuation of this interactionist tradition in research on socio-economic phenomena, treating these phenomena as one of the aspects of everyday life, which, in their structure, do not differ from the rules that constitute this everyday life in human experiences (Karp, Yoels, and Vann 2003; Jacobsen 2009).

\section{Methodology}

The study was based on two methodological approaches. The first is analytical ethnography as a special type of fieldwork for collecting empirical data (cf. Lofland 1970; 1995; Snow, Morrill, and Anderson 2003; Anderson 2006). The second is the grounded theory methodology, which is a strategy for working with data and organizing the entire research process (Glaser and Strauss 1967; Konecki 2000; 2005; 2012; 2019; Gorzko 2008; Charmaz 2009). Such a juxtaposition is not accidental because both approaches are based on the same assumptions as to the criteria of effective research, while simultaneously striving to develop theoretical effects based on systematic empirical work. The first approach shows the researcher how to work in the field, the second one-how to work with the data from the field, which makes both approaches complementary. The consequence of the adopted research strategy was the limitation of preconceptualization and the generation of subsequent hypotheses as an effect of the conducted analyses, and not a starting point for them, as is the case in the classical research scheme.

The research was conducted in five locations-large urban marketplaces in four cities in Poland.

At this point, it is worth adding that each of the examined places had the character and formally regulated status of a marketplace-a permanent, continuously operating, or at regular intervals-a commercial space where various products are offered-food, clothing, household goods, and others, mostly new goods, provided by vendors with a specific and legally regulated professional status-marketplace and mobile merchant. In this sense, the researched bazaars differed both legally and culturally from fairs (jarmarki in Polish) also present in Poland (operating occasionally) or flea markets (pchle targi) where second-hand, cheap goods are sold, offered by people who do not necessarily deal with trade daily.

The choice of particular locations was related to the course of the analytical process and the emerging needs to make comparisons and differentiate contextual elements to capture the processes and properties of processes associated with the studied phenomena, regardless of the situational conditions of their occurrence. The data were collected in stages, 
in 2007-2012, and comparatively in 2016-2019, with a schedule developing gradually along with the progress of analytical work and the emergence of new premises for theoretical sampling.

For a community as diverse as a merchant community of the urban bazaar, and with research conducted in five different locations, it was necessary to implement several data collection strategies. Due to their importance and place in the research process, they can be divided into basic and auxiliary. The methods used include:

- Non-participant ethnographic observations

- Participant ethnographic observations

- In-depth interviews with vendors

- Semi-structured interviews with buyers

- Observations while accompanying the buyers (shadowing)

- Observations with a standardized list of information

It is also worth adding that the collected data were a combination of analytical and evocative data (see: Ellis and Bochner 2016; Kacperczyk 2017), constituting a collection of observations and information obtained through various techniques of data gathering, as well as recorded experiences and feelings of a researcher involved in the activities of local merchant communities as part of ethnography. The author spent three months at one of the marketplaces, actively selling as a merchant's assistant, while overtly taking notes on the observations. At the next marketplace, for a total of three years, he conducted regular observations and interviews, remaining fully in the role of a researcher, but at the same time getting to know the merchant community from the inside, gaining their trust and acceptance. The next three marketplaces were visited by the researcher occasionally, and the collected data were used to supplement or guide theoretical sampling and analytical constant comparisons.

\section{Empirical Findings}

Understanding the activities and interactive strategies of merchants that make the overall social organization of urban marketplaces requires comprehension and insight into the context in which these phenomena occur. An urban marketplace is a specific place, on the one hand being a space of mixing local and supra-local cultures, and on the other hand, the subject to legal and formal regulations. The same goes for the work of marketplace vendors, which in its multifaceted nature is both focused on earning (sales is the only or the main source of income) and on creating a local community of merchants of the same marketplace.

For this article, key analytical concepts and threads were selected from the research results. A short presentation of contextual aspects introduces the description of the most important analytical categories of the social organization of activities to the presentation of two primary interactional ventures creating a spatial, relational, and interactional order in the social dimension of the marketplace, and the presentation of the key consequences of such an order at the economic level of the market.

\section{The Contextual Aspects of the Studied Phenomena}

During the research, four key aspects of the context of marketplaces activities were identified, which at every level of analysis, from micro to macro, shape the external conditions of the social organization of trade activities. 
The first of the contextual aspects is the trade culture prevailing in Poland, the most important element of which-bargaining for sale prices-is limited, and sometimes even non-existent, in the context of the conducted analyses. While price negotiation is permissible for specific transactions (such as the purchase of a car or wholesale purchase of goods, etc.), it rarely occurs in the case of everyday purchases of common goods, and these are offered at urban bazaars in Poland.

Another, apart from the trade culture, contextual aspect of the studied phenomena turned out to be the collective and spatial organization of the marketplace activity. Bazaar trades are carried out in specially designated places. Each merchant deciding to trade within the marketplace must accept the fact that they will be operating in the vicinity of other merchants, and more broadly-as a group. This also shows the constitutive feature of the marketplace the necessary condition for which existence and operation is the commercial activity of many merchants. This obvious interdependence of bazaar vendors has a crucial meaning for merchants, as well as for the exploitation of the entire market. Collective action at the marketplace guarantees a relatively continuous flow of buyers. Contrarily, independent street vending would deprive buyers of free and wide choices commonly associated with the marketplace, forcing vendors to develop more advanced tactics of striving for customers.

The third contextual aspect is the identity of a merchant profession. The connection with the trade in the marketplace as an everyday, primary workplace brings further consequences; working in the marketplace becomes a source of identity references for vendors, which will ultimately result in the crystallization of the professional identity of the merchants, both in the individual and collective dimension, in creating a professional group. It is significant, however, that the professional group of merchants is so extensive and diverse that it does not shape a coherent pattern of collective identity, transmitted through secondary socialization or the symbolism (see: Strauss 1962; 1969), and the culture of the profession. Therefore, in their case, it can be stated that professional identity is neither a component nor a subject of reflection for subjective identity (self-identity; cf. Goffman 1963), but the identification of the self and others as merchants plays a key role in the further organization of the social relationships on the bazaar (for more detailed analysis of the identity work among merchants, see: Marciniak 2016).

The fourth of the contextual aspects identified in the study are the formal and legal frameworks for merchant activity. The validity of formal norms shapes the methods (barriers and possibilities) of starting merchant activity within the marketplace, the features of marketplace work, and the scope of legality and illegality of activities undertaken at the marketplace.

The last contextual aspect is the locally produced cultural and ethnic order, the heterogeneity of the merchant community, as well as the group of customers and visitors to the marketplace. At marketplaces, you can meet people of various origins and biographies, whose individuality sometimes disappears in the "melting pot" of the marketplace, and sometimes it clearly shows up on the surface. Of course, you can try to illustrate the social structure of individual marketplaces by looking for something similar to a scaffold, but a long-term comparative study shows how fragile, fluid, and unstable this structure is. This community is constantly chang- 
ing. In annual, weekly, and sometimes daily cycles, traders repeatedly go from high profit to the limit of loss, from stocking to a shortage. They change their strategies, product range, and specializations. Sometimes they work constantly and sometimes seasonally. Sometimes they work together, and sometimes they work separately.

\section{The Social Organization of Merchants' Activities}

The conducted research has shown that the everyday understanding of the marketplace as a place of unlimited competition and activities aimed at concluding mutually beneficial fairs differs significantly from reality. There are several identified, analyzed, and described interactional phenomena organizing the activities of merchants.

\section{Focus on Profit and Sales}

Profit is the primary goal of any marketplace merchant. Regardless of the type of goods offered, trade experience, or place in the market community, each vendor strives to obtain a satisfactory profit. Merchants' understanding of profit varies, although the most common and shared implicitly is one in which profit is the money merchants have from net trading after subtraction of monthly marketplace fees and taxes. Therefore, when it comes to possible profit, buyers mainly talk about how much can be earned, while a satisfactory profit is, in their understanding, the amount they would like to have after covering the costs. The level of satisfactory profit in the declarations of buyers is very varied and fully individualized. Based on the data obtained in the study, it can only be concluded that factors such as the type of assortment, the position of the trade, or the market where the merchant works change the range of satisfactory profits; however, individual amounts indicated by buyers may differ significantly within one assortment category.

The satisfactory profit is variable because it is directly related to the profit that can be obtained in a given situation (with resources, at a given time of the year, etc.). In light of the data, it can be concluded that for vendors, the goal, much more important than increasing profit, is to keep it at an even level and minimize the decline in profit resulting from seasonality.

A full understanding of the earning goals set by market merchants may help us learn, apart from the level of satisfactory profit, also the profit necessary to obtain weekly, that is, the minimum that merchants must earn to have enough to cover the fees and, in their opinion, to have enough to live on.

The satisfactory profit and necessary profit are the two boundaries within which vendors undertake their sales activities while shaping specific goals. First of all, each merchant strives to work out a minimum as a subjective break-even point for their activities. Secondly, after exceeding this threshold, merchants try to increase revenues and move away from the minimum threshold. However, increasing profit has its limit at the level of satisfactory profit, which is the limit in the sense that after reaching it, the determination to increase revenues significantly weakens.

Operating in the range of two profit boundaries, necessary and satisfactory, and in the annual cycle of changes of seasons, merchants develop a rich repertoire of strategies to intensify and weaken sales activities. Following the situational needs of customers and enriching, expanding, or replacing the offered assortment, striving for regular customers are among the most important. 
Profit and sales are shaped in the annual cycle of decreases and increases, at the same time shaping the scope and intensity of merchants' activity. Seasonality, it might seem, should primarily affect buyers offering fruits and vegetables, that is, products strongly related to periodic supply and demand. However, the collective nature of marketplace trade means that the decline in demand for agri-food products also affects merchants offering other products. When customers stop coming to the marketplace for fruits and vegetables, the chances of selling clothes or industrial products also decrease. On the other hand, customers interested in buying clothes at the market can also do grocery shopping. Thus, the essence of the mercantile activity in the marketplace appears, namely, that it is a related activity.

\section{Basic Interactional Categorizations: Type of Goods and Type of Work}

The goods offered by the merchant are the primary trading resources and, at the same time, the main factor that categorizes the merchants in the marketplace. However, it is not about a purely theoretical categorization (external to the reality of the marketplace) regarding the type of assortment, but a practical categorization that merchants make in their daily interactions. During the field research, it was possible to identify eight dimensions of the characteristics that merchants use to categorize the offered goods. Marketplace assortment can be identified as:

1. Sourced vs. Manufactured (handmade or cultivated)

2. Legal vs. Illegal

3. Year-round vs. Seasonal

4. New vs. Used

5. Good vs. Defective (in terms of its quality)

6. Reliable vs. Doubtful (in terms of its origins)
7. Universal vs. Unique (in terms of the availability on the particular marketplace)

8. Polish vs. Chinese ${ }^{1}$ (in terms of its symbolic combination of origin and quality)

Depending on the categorization of the offered goods, work may be identified and interpreted in various ways by buyers. The study managed to reconstruct four varieties of trading work at the marketplace distinguished by merchants:

a. Selling is an activity undertaken by merchants offering legal, good, and reliable goods. Often the condition is also that the product is not "Chinese." Selling is displaying goods of satisfactory quality and proven features, consistent with what the customer is informed about.

b. Crookering is the activity of offering a good that differs to some extent from its properties presented during an interaction with a customer. It will still be goods with generally good quality characteristics, in the sense that it will not be defective or non-functional, and of a relatively certain origin. Crookery will consist of increasing the presented values above the actual ones of a given product.

c. Cheating is an activity related to the trade of a defective product of questionable origin, as well as a "Chinese" product if it is offered as a domestic product, or a second-hand product if it is displayed by the merchants as new.

\footnotetext{
${ }^{1}$ The term "Chinese" is an in vivo code in the analysis, taken directly from the language of street vendors. At the same time, it refers to the broader context of Polish culture in which the adjective "Chinese" is used to describe a specificity of goods massively imported from South-Eastern Asia and customary associated with low quality and low price.
} 
Cheating occurs whenever a customer purchases a product completely unaware of the actual characteristics of the goods, assuming that knowing them would discourage them from buying.

d. Crime fiction (criminal trafficking). The term "crime fiction" was an in vivo code in the analysis, taken directly from the language of marketplace merchants who use it to describe activities related to the trading of illegal goods. Crime fiction may therefore refer to offering weapons, drugs, counterfeit documents, pirated software, stolen items, but also medicines, alcohol, cigarettes, pyrotechnic materials, and fuels in the marketplace.

\section{Creating a Horizontal Distance}

Based on the categorizations, merchants make mutual evaluations of their actions, assortments, and motives. Thus, in this way, groups of the same and different types of the assortment and the types of work appear: groups that are accepting others belonging to their category and relatively not accepting those who do not belong to it among the marketplace community. However, the lack of acceptance for merchants assigned to other categories is expressed very subtly in the realities of the marketplace, as it cannot contribute to the elimination of the category. The overriding feature of the market, which is responsible for its attractiveness to customers, is the multiple-choice and diversity, and each category of merchants contributes equally to this achievement.

An action that allows them to achieve the effect of differentiation without fighting dissimilarity is distancing, the purpose of which is to distance themselves from other categories of merchants. A significant fea- ture of horizontal distancing is the significant importance of possible ethnic diversity. In the everyday experience of bazaar vendors, more important than the ethnic origin is belonging to the category of the work, except situations when belonging to an ethnic group is associated with the category of the offered goods or the category of trading work.

The key basis for the distancing that takes place at marketplaces is the way merchants evaluate the moral activity of other merchants operating within the marketplace. This assessment is always comparative, based on ones' commercial practice. Distancing as an activity undertaken to construct a moral distance has two basic forms:

- Avoiding-related to the lack of acceptance for activities considered inconsistent with the merchant's moral standards and minimizing the possible exchange, cooperation, and communication with vendors belonging to the negatively assessed category of trading work.

- Engaging-associated with expressing support for actions in line with individual moral criteria and striving to strengthen relationships, intensify contact, and cooperation with vendors belonging to the positively assessed category of trading work.

Although in colloquial language, creating distance is associated only with avoidance (as a form of enlarging a distance), in the interactional dimension, constructing distance is based on these two activities, avoiding one and, at the same time, getting closer to the other. Distancing is a process of negotiating space in between (in a spatial and interactional sense), which may be closer or more distant, setting a dynamic order of interactions. 
Table 1. Distancing of particular categories of merchants from other categories.

\begin{tabular}{|c|c|c|c|c|c|}
\hline $\begin{array}{l}\text { Categories of } \\
\text { merchants }\end{array}$ & $\begin{array}{l}\text { Other selling } \\
\text { merchants }\end{array}$ & $\begin{array}{l}\text { Other crooking } \\
\text { merchants }\end{array}$ & $\begin{array}{l}\text { Other cheating } \\
\text { merchants }\end{array}$ & $\begin{array}{l}\text { Other criminal } \\
\text { merchants }\end{array}$ & $\begin{array}{l}\text { Approach to } \\
\text { distancing }\end{array}$ \\
\hline $\begin{array}{l}\text { Merchants } \\
\text { selling } \\
\text { towards... }\end{array}$ & Engaging & Avoiding & Avoiding & Avoiding & $\begin{array}{c}\text { Strongly } \\
\text { distancing }\end{array}$ \\
\hline $\begin{array}{l}\text { Merchants } \\
\text { crooking } \\
\text { towards... }\end{array}$ & Neutrality & Engaging & Avoiding & Avoiding & $\begin{array}{l}\text { Moderately } \\
\text { distancing }\end{array}$ \\
\hline $\begin{array}{l}\text { Merchants } \\
\text { cheating } \\
\text { towards... }\end{array}$ & $\begin{array}{l}\text { Neutrality / } \\
\text { Avoiding }\end{array}$ & Neutrality & Engaging & Neutrality & No distancing \\
\hline $\begin{array}{l}\text { Criminal } \\
\text { merchants } \\
\text { towards... }\end{array}$ & $\begin{array}{l}\text { Neutrality / } \\
\text { Avoiding }\end{array}$ & Neutrality & Neutrality & Engaging & No distancing \\
\hline
\end{tabular}

Source: Self-elaboration.

Table 2. Moral distancing-actions and interactional strategies.

\section{Form of distancing}

\section{Avoiding}

Limited neighborhood cooperation

Not engaging in joint social activities

Limited information transfer

Do not recommend/advise customers

Formal communication

Applying the "us-them" dichotomy

\section{Engaging}

Extensive neighborhood cooperation

Engaging in joint social activities

Extensive information transfer

Recommending regular customers

Informal communication

Applying the "we" association

Source: Self-elaboration.

Moral distancing, in both its forms of avoidance and engagement, can result in many different activities and interaction strategies.

The lack of acceptance for activities considered inconsistent with one's moral standards results in the avoidance and minimization of exchange, cooperation, and communication with vendors belonging to the negatively assessed category. Avoiding merchants limit interactions in the neighborhood, and their activities come down to a completely basic exchange of favors, to a limited extent and 
frequency. A merchant who distances from their neighbor in a stall may, for example, in response to a request, look after the neighbor's stands in their absence, but they will not sell for them anymore; in an emergency (e.g., a storm), they may help to temporarily hide the goods, but they will not be constantly lending storage space. They will not engage in joint social activities, refusing invitations to join the entertainment others organize in their spare time at the marketplace, or conversations. Avoided merchants are only provided with key information in the possession of the distancing merchant that has an impact on the overall functioning of the bazaar. Information critical for further work will be provided (e.g., about the police raid, about the upcoming snowstorm), but not the information that could facilitate their work (about the client's interest during their absence, about changes in rates, new requirements, etc.). And that is also connected with the limited recommendations. Most often, avoiding merchants simply do not inform their regular customers about the availability of a given product from a distant merchant, but it may also happen that they advise against buying at a specific stand, warning their best customers against faulty or uncertain goods. The distancing strategies are also visible in direct communication, which in this case is highly formal, with the prevalence of indirect and polite phrases, the use of the form "Mr./Mrs." towards known merchants, and the formulation of the requests in an official manner (examples from the field notes):

I kindly ask you to do your suspicious business somewhere else.

Please take a step off.

Would you be so kind, Mr. Jones, and lend me a lighter.
In the opposite case, there are engaging strategies, based on the extensive cooperation, communication, and everyday activities, and perceived by merchants as a value-based process.

That is a matter of similar views, but also values. It is the best, the easiest way to talk to those who share such values. There is a group of us here, maybe a small group, but very well-known, we see the same situation in the marketplace, we have similar aspirations. We can easily communicate with each other, and often also work out a common position towards problems and towards other groups at the market here. [Merchant, Bałucki Bazaar, Lodz]

Merchants help each other in exceptional and everyday situations, lend trade resources, and try to facilitate work. Help can often go beyond the marketplace itself and be related, for example, to acquiring goods, joint trips to a warehouse, or dealing with official formalities. Such cooperation is also based on demonstrating trust and, for example, entrusting the stand (and sales and billing) in the absence of the vendor. In their spare time, when there are not many customers at the marketplace, merchants play cards, checkers, or other board games. It is also popular to tell various stories, jokes, show photos and videos on the phone. They read the press, exchange it, and discuss threads in it. They show each other photos of the family, talk about their private lives. They exchange news constantly, share their knowledge, provide tips and suggestions. They inform each other of key and side events, which is not necessary, but can be helpful in commercial activities, procurement, assortment changes, and customer approach. And they recommend intensively, inform their customers about the availability of a good and reliable product, or suggest that the 
goods available from a particular vendor are worthy of attention as a whole. Recommendations are an element of building relationships with regular customers; therefore, only proven products and trusted vendors are recommended. Finally, they communicate directly, referring to each other by name or pseudonyms, formulating requests and suggestions in a confidential, free, and direct manner (examples from the field notes):

Honey, give me your pen.

Adam, take a look here for a moment because I'm going to the car.

I will help you, baby.

Creating a moral distance is a step-by-step process, starting with identifying your category of belonging, engaging in contact with merchants of your category, and building a resource of shared interpretations regarding other trading practices, to undertaking activity towards vendors of other categories.

Moral distance creates a horizontal order of relations between merchants because it does not contain a uniform criterion for deciding what is better and what is worse, what is "more" and what "less."

\section{Creating a Vertical Distance}

Referring to the primary trade resources owned by everyone who undertakes business in a marketplace, merchants begin to distinguish between different states of ownership, which are of great importance for the position that a merchant can occupy in the community of a given marketplace, influencing the agency and autonomy of decisions.
Merchants are fully aware of the differences in ownership and, more importantly, the resulting distinctions. Experiencing the market reality, they easily identify those who have more and can do more and those who have less and therefore can also do less. Defining such differences is, in fact, defining the situation of not equaling others or surpassing others from the perspective of a specific merchant, which is directly related to the feeling of disadvantage (towards others) or distinction (among others) that develops in vendors. The perceived inequalities contribute to the second, apart from moral distancing, the process of dividing the merchant market, namely, hierarchization, which results in the appearance of a vertical distance between merchants, on a scale from those who have the least and are the most dependent, to those who have the most and can enjoy great independence (decisions, actions).

Hierarchization is based on three basic types of inequalities distinguished by merchants: inequality of profit, inequality of knowledge, inequality of influence. Vertical distance, constructed by identifying inequalities, relating to them, and explaining one's position in the community of marketplace merchants, is a phenomenon much more dynamic than the horizontal distance, and its dynamics resembles the so-called basket of crabs (according to Bischof-Kohler 1990; 1992). In such a system, each participant of the hierarchized reality may, depending on their motivations, strive to occupy higher positions, which is not met with resistance from others, but may only intensify the efforts of others to raise their ranks. As is the case in a basket filled with crabs, everyone climbs one after the other, but it does not arouse fights or disciplining, but only a general striving to take the highest possible position. Such an order is characterized by 
high dynamics and relative impermanence, constant falling and climbing, losing and regaining position.

\section{Constructing the Order of Relations}

Distancing and hierarchization, as immanent processes taking place in the marketplace community, result in the creation of a relationship space experienced by vendors. Each merchant takes a specific position in this space, determined by a certain horizontal (moral) distance to other merchants and a vertical distance (hierarchy) to others. Other merchants may also be in the same or a similar position, together creating a specific group of a given marketplace remaining in the same position concerning other (groups of) merchants.

Although the categories of inequality and morality are the same for each marketplace, the occurrence of specific groups of relationships (close in terms of both distances) will be varied and dependent on the local situation in a given marketplace.

By tightening cooperation and contacts within their group, merchants begin to arrange relations with the closest groups due to the vertical and horizontal distance, thus creating a network of relations, defining the scope of possible contacts and cooperation, still based on the criterion of similarity. Although other groups do not have the same position due to the state of property and morality of the action, they are still in a relational neighborhood close enough to concentrate possible cooperation among the entire community of the marketplace.

Two trends can be observed in the space of marketplace relations:
- Striving for belonging. Each merchant is looking for groups with a similar state of ownership and similar morality in action to have others around them who share the perspective of perceiving the reality of the marketplace and share the axionormative standards manifested in the assumptions about possible ways of working (selling).

- Striving for similarity. Each merchant, while remaining in contact with their group of relations, strives to equalize the state of the property to the level of other members of a given group and to adopt moral standards shared in the group.

As a result of the occurrence of both of these tendencies, the initial assignment to a specific group of relations manifests in a deepening and tightening of contacts and intensification of cooperation. For the existence of any network of relationships formed from close groups, two aspects determining the specificity, scope, and durability of such relationships will be of key importance, namely, the sources of shared experiences and the dependence of cooperation.

In the space of marketplace merchants' accounts, one can see dependencies, which Mark Granovetter $(1973 ; 1983)$ called "strength of weak ties." Relationships connecting vendors, both in relationship groups and in networks, are neither particularly affective nor intimate and not necessarily long-lasting.

Merchants selling clothing from kiosks (a type of market stall) remain in the network of relationships, among others, with merchants trading citrus fruits from open stalls. As support, vendors with better 
equipment and access to electricity offer the possibility of using utilities and storage space, storing some products after the end of the trading day. Merchants from the open stalls take advantage of the opportunities offered by kiosk merchants, in return offering protection through contacts with local street hooligans. After such an exchange for a long time, mutual aid became established. Kiosk merchants resigned from paying security companies, and at the same time, decided to leave even valuable goods overnight at the kiosk (with the certainty of protection). On the other hand, the merchants from the open stalls decided to organize their work differently, storing products in kiosks on a daily basis and resigning from the daily delivery and collection of goods. That led to a mutual dependence of cooperation when merchants from kiosks without support would be in danger (theft, vandalism), and merchants from stalls would have serious logistical issues. This relationship became so solidly established that in the opinion of both groups of merchants, a sudden break of this relationship turned out to be impossible. [excerpt from the field notes, Jeżycki Bazaar, Poznan]

\section{The Consequences of the Social Organization on Merchants' Activities}

The organization of merchants' activities, constructed by connecting and dividing forces, dynamizing and stabilizing, resonates in the economic operation of the marketplace, reflecting the created order of relations on phenomena such as competition or prices, at the same time showing the extent to which economic processes are embedded (see: Granovetter 1973; 1983) in social processes.

Thus, in the socially organized activity of marketplace merchants, there may be two paradoxes in the economic context.
The paradox of competition of a marketplace that is diversified in terms of morality and the inequality of its subjects lies in the fact that the most competitive vendors are, at the same time, the closest in terms of similar experiences and their position in the community. In other words, in the realities of a marketplace, direct competition comes from similarity, and at the same time, similarity restricts competition.

The price paradox of the marketplace, which consists in the fact that with a large supply and variety of products, and even the existing variety of prices, in reality, there are no price alternatives for buyers because the difference in prices is not a sign of market competition, but the market agreement between merchants concerning the qualitative incompatibility of goods. In other words, a different price of the same products is information that they are different products (superficially the same, qualitatively different). The setting of prices by merchants is the setting of a specific applicable price, from which deviation may only be related to a change in the properties of the product (qualitative and functional changes). It can take the form of setting the starting price of a good, adjusting prices, and correcting prices to the level prevailing in the marketplace.

\section{Summary}

The conducted research allowed us to generate several coherent and conceptually saturated hypotheses concerning the context of market merchants' activities and the processes taking place inside the marketplace community and organizing these activities (for further reading see: Marciniak 2016).

The context of bazaar vendors' activities is not a set of determinants, but a framework or, as Herbert 
Blumer (1986) would define them, sets of factors with which traders must cope and learn to use, thus shaping their activities.

The socially organized venture of marketplace merchants is a social activity in the meaning of George Mead or joint action, according to Herbert Blumer (1986; see also: Gillespie 2011; Azarian 2015). The specificity of such an activity is the matching of participants who establish a joint action in which they will engage and then mutually interpret and define their activities while shaping the collective action.

\section{References}

Anderson, Leon. 2006. "Analytic Autoethnography." Journal of Contemporary Ethnography 35(4):460-471.

Azarian, Reza. 2015. "Joint Actions, Stories and Symbolic Structures: A Contribution to Herbert Blumer's Conceptual Framework." Sociology 51(3):685-700.

Baker, Wayne and Robert Faulkner. 2004. "Social Networks and Loss of Capital." Social Networks 26:91-111.

Bischof-Kohler, Doris. 1990. “Frau und Karriere in psychobiologischer Sicht [Woman and Career from a Psychobiological Point of View]." Zeitschrift für Arbeits- u. Organisationspsychologie 34:17-28.

Bischof-Kohler, Doris. 1992. “Geschlechtstypische Besonderheiten im Konkurrenzverhalten: Evolutionäre Grundlagen und entwicklungspsychologische Fakten [Gender-Specific Characteristics in Competitive Behavior: Evolutionary Basics and Developmental Psychological Facts]." Pp. 251-281 in Personalpolitik aus der Sicht von Frauen. Was kann die Personalforschung von der Frauenforschung lernen? [Personnel Policy from the Perspective of Women. What Can Human Resources Research Learn from Women's Research?], edited by G. Krell and M. Osterloh. Munich: Rainer Hampp Verlag.

Blumer, Herbert. 1986. Symbolic Interactionism: Perspective and Method. Berkeley, CA: University of California Press.
The network of dependencies created between buyers and groups of buyers (similar in the distance) shows the strength of weak ties (Granovetter 1973; 1983), not based on intimacy or emotional closeness, but influencing the actions of each individual and everyone as a market collective. There are also visible consequences of the social organization of merchants' activities, which are reflected not only in the social order of the marketplace, but also in the economic order.

However, a further generalization of conclusions, going beyond the context of marketplace trade, will require further comparative research.

Blumer, Herbert. 1990. Industrialization as an Agent of Social Change: A Critical. Analysis. New York: Aldine de Gruyter.

Carruthers, Bruce and Sarah Babb. 2000. Economy/Society: Markets, Meanings and Social Structure. Thousand Oaks, CA: Pine Forge Press.

Charmaz, Kathy. 2009. Teoria ugruntowana. Praktyczny przewodnik po analizie jakościowej [Constructing Grounded Theory. Practical Guide Through Qualitative Analysis]. Warsaw: Wydawnictwo Naukowe PWN.

Chiffoleau, Yuna and Catherine Laporte. 2006. "Price Formation: The Case of the Burgundy Wine Market." Reveu française de sociologie 5:157-182.

Chiu, Chihsin. 2013. "Informal Management, Interactive Performance: Street Vendors and Police in a Taipei Night Market." International Development Planning Review 35(4):335-352.

DiMaggio, Paul. 1990. "Cultural Aspects of Economic Organization and Behavior." Pp. 113-136 in Beyond the Market Place: Rethinking Economy and Society, edited by R. Friedland and A. F. Robertson. New York: Aldine de Gruyter.

Ellis, Carolyn and Arthur Bochner. 2016. Evocative Autoethnography: Writing Lives and Telling Stories. Walnut Creek, CA: Routledge. 
Geertz, Clifford. 1978. "The Bazaar Economy: Information and Search in Peasant Marketing." The American Economic Review 68(2):28-32.

Gillespie, Alex. 2011. "Exchanging Social Positions: Enhancing Intersubjective Coordination within a Joint Task." European Journal of Social Psychology 41:608-616.

Glaser, Barney and Anselm L. Strauss. 1967. Discovery of Grounded Theory: Strategies for Qualitative Research. Chicago: Aldine do Gruyter.

Goffman, Erving. 1963. Stigma: Notes on the Management of Spoiled Identity. Upper Saddle River, NJ: Prentice-Hall.

Gorzko, Marek. 2008. Procedury i emergencja. O metodologii klasycznych odmian teorii ugruntowanej [Procedures and Emergence. On the Methodology of Classical Varieties of Grounded Theory]. Szczecin: Wydawnictwo Uniwersytetu Szczecińskiego.

Granovetter, Mark. 1973. "The Strength of Weak Ties.” American Journal of Sociology 78(6):1360-1380.

Granovetter, Mark. 1974. Getting a Job. A Study of Contacts and Career. Harvard: Harvard University Press.

Granovetter, Mark. 1983. "The Strength of Weak Ties: A Network Theory Revisited." Sociological Theory 1:201-233.

Granovetter, Mark. 1985. "Economic Action and Social Structure: The Problem of Embeddedness." American Journal of Sociology 91(3):481-510.

Granovetter, Mark. 1992. "Economic Action and Social Structure: The Problem of Embeddedness." Pp. 22-45 in The Sociology of Economic Life, edited by M. Granovetter and R. Swedberg. New York, London: Routledge.

Ho, Karen. 2009. Liquidated: An Ethnography of Wall Street. Durham, NC: Duke Press.

Hughes, Everett C. 1958. Men and Their Work. Glencoe, IL: Free Press.

Jacobsen, Michael, ed. 2009. Encountering the Everyday. Houndmills: Palgrave Macmillan.

Kacperczyk, Anna. 2017. “Rozum czy emocje? O odmianach autoetnografii, epistemologicznych pomostach i przepaściach między nimi [Reason or Emotions? On the Varieties of Autoethnography Epistemological Bridges and Gaps between Them]." Kultura i Społeczeństwo LXI(3):127-148.
Karp, David, William Yoels, and Barbara Vann. 2003. Sociology in Everyday Life. Long Grove, IL: Waveland Press.

Konecki, Krzysztof T. 2000. Studia z metodologii badań jakościowych. Teoria ugruntowana [Studies in the Methodology of Qualitative Research. Grounded Theory]. Warsaw: Wydawnictwo Naukowe PWN.

Konecki, Krzysztof T. 2005. “Teoria ugruntowana a kontekst odkrycia. Naturalna historia pewnego badania [Grounded Theory and Serendipity. Natural History of a Study]." In W kręgu socjologii interpretatywnej-zastosowanie metod jakościowych [In the Area of Interpretative Sociology - The Use of Qualitative Methods], edited by J. Leoński and A. Kołodziej-Durnaś. Szczecin: USz, Economicus.

Konecki, Krzysztof T. 2007. “Działanie przedsiębiorcze. Auto-praca nad tożsamością a społeczny proces konstruowania motywacji do działania przedsiębiorczego [Entrepreneurial Actions. Auto-Work on Identity and the Social Process of Constructing Motivation for Entrepreneurial Activity]." Pp. 72-115 in $W$ kręu socjologii interpretatywnej. Badania jakościowe nad tożsamościa [In the Circle of Interpretative Sociology. Qualitative Research on Identity], edited by J. Leoński and U. Kozłowska. Szczecin: Economicus.

Konecki, Krzysztof T. 2008. “Economic Sociology as a Sociology of Economic Action." In Management: Qualitative And Quantitative Research, edited by A. Nowak and B. Glinka. Warsaw: Wydawnictwo Naukowe Wydziału Zarządzania Uniwersytetu Warszawskiego.

Konecki, Krzysztof T. 2012. “Wizualna teoria ugruntowana. Podstawowe zasady i procedury [Visual Grounded Theory. The Basic Rules and Procedures]." Przegląd Socjologii Jakościowej 8(1):12-45.

Konecki, Krzysztof T. 2019. “Visual Images and Grounded Theory Methodology." Pp. 352-374 in The SAGE Handbook of Current Developments in Grounded Theory, edited by A. Bryant and K. Charmaz. London: Sage.

Kurczewski, Janusz. 2010. "Fenomenologia bazaru [The Phenomenology of the Bazaar]." Pp. 31-50 in Wielkie bazary warszawskie [Great Warsaw Bazaars], edited by J. Kurczewski, M. Cichomski, and K. Wiliński. Warsaw: Trio.

Lofland, John. 1970. "Interactionist Imagery and Analytic Interruptus." Pp. 35-45 in Human Nature and Collective Behavior: Papers in Honor of Herbert Blumer, edited by T. Shibutani. New Brunswick, NJ: Transaction Books.

Lofland, John. 1995. "Analytic Ethnography." Journal of Contemporary Ethnography 24:4-24. 
Marciniak, Lukasz. 2016. Bazary: kooperacja czy konkurencja? [Bazaars: Cooperation or Competition?]. Lodz: Wydawnictwo UŁ.

McKenzie, Roderick. 1921. "The Neighborhood: A Study of Local Life in the City of Columbus, Ohio." American Journal of Sociology 27(2):145-168.

Misztal, Bronisław. 1971. "Zróżnicowanie społeczne zbiorowości przekupniów na Bazarze Różyckiego [Social Diversity of the Community of Vendors at the Różycki Bazaar]." Studia Socjologiczne 3.

Moeran, Brian. 2006. Ethnography at Work. Oxford: Berg Publishers.

Papadantonakis, Max. 2020. “Black Athenians: Making and Resisting Racialized Symbolic Boundaries in the Greek Street Market." Journal of Contemporary Ethnography 49(3):291-317.

Park, Robert and Ernest Burgess, eds. 1925. The City. Chicago: University of Chicago Press.

Prus, Robert. 1989a. Pursuing Customers. London: Sage.

Prus, Robert. 1989b. Making Sales. London: Sage.
Rosales, Rocio. 2013. "Survival, Economic Mobility and Community among Los Angeles Fruit Vendors." Journal of Ethnic and Migration Studies 39:697-717.

Smith, Charles W. 1990. The Social Construction of Value. Berkeley, CA: University of California Press.

Snow, David, Charles Morrill, and Leon Anderson. 2003. “Elaborating Analytic Ethnography: Linking. Ethnography and Theoretical Development." Ethnography 4:181-200.

Strauss, Anselm L. 1962. "Transformations of Identity." Pp. 6385 in Human Behavior and Social Processes, edited by A. M. Rose. Boston: Houghton Mifflin Company.

Strauss, Anselm L. 1969. Mirrors and Masks. San Francisco: The Sociology Press.

Velthuis, Olav. 2003. “Symbolic Meanings of Prices: Constructing the Value of Contemporary Art in Amsterdam and New York Galleries." Theory and Society 32(2):181-215.

Wasserman, Stanley and Katherine Faust. 1994. Social Network Analysis. Methods and Applications. Cambridge: Cambridge University Press.

\section{Citation}

Marciniak, Lukasz. 2020. “The Social Organization of Merchants' Activities. An Interactionist Study of Urban Marketplaces.” Qualitative Sociology Review 16(4):106-121. Retrieved Month, Year (http://www.qualitativesociologyreview.org/ENG/archive_eng. php). DOI: http://dx.doi.org/10.18778/1733-8077.16.4.07 